\title{
Some Financial Measures For The Busy Small Business Owner
}

Ronald J. Patten, DePaul University, USA

Charlene D. Patten, Procter \& Gamble, USA

\begin{abstract}
Small business owners have a number of things that demand their attention. Yet, virtually all of them are concerned with how their business is doing. Many suggestions have been made in an effort to address that concern.

In this paper, a straight-forward approach is suggested, which is not overly complicated yet not overly simplistic either. With the use of five financial measurements, the busy small business owner can gain a keen appreciation of how the business is doing. The measures serve as indicators of various aspects of the business and, at the same time, present a solid overall picture. Further action is then dependent on the time, inclination, and resources of the owner.
\end{abstract}

Keywords: Creating Value; Financial Measurements; Small Business Owner

\section{INTRODUCTION}

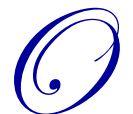

ver the years, the authors have heard a number of small business owners say that they have financial statements consisting of a balance sheet, income statement, and cash flow statement. However, these owners indicate that they have heard about management accountants, whom they cannot afford to hire, who can suggest useful measurements that utilize information from the financial statements that can help the owners make more informed decisions. Typically, these small business owners also indicate that they do not want to be inundated with a flurry of numbers. They almost beg, "is it not possible to get something useful, yet reasonably simple?" Far be it to offer a one-size-fits-all solution. Nonetheless, this paper offers a set of five measurements that will go a long way toward helping these owners make more informed decisions. Isn't that what management accounting is all about?

The following set of five metrics is suggested. You may refer to them as the Fab Five or whatever your predilection is for titles.

- Sales or Operating Revenue

- Gross Margin

- Operating Profit Margin

- Operating Asset Turnover

- Free Cash Flow used.

Each of these metrics will be examined in order and will be followed with a discussion of how they can be

\section{Sales Or Operating Revenue}

This number can be found in the Income Statement or, as some of the owners say, the P \& L, and is not to be used in isolation. Rather, it should be presented for several years (Gibson, 2004). In examining these figures, one is looking for the percentage change from year to year. Hopefully, the business is experiencing an increase over time. Regardless, this metric indicates what magnitude of growth or decline the business has experienced and 
provides an important indicator of the company's health. As all business owners know, without revenue the business is in dire straits. Note that this measurement presents a starting point for further analysis, if the owner is so inclined and the time and expertise is available to do so. The effect of changes in sales volume quantities and changes in the selling price per unit can be identified so as to zero in on the driver behind the changes in revenue.

\section{Gross Margin}

This metric is widely used and indicates the difference between sales revenue and the cost of the goods that have been sold (Lundholm et al., 2007). When the gross margin is expressed as a percentage of sales, this number can be examined over time. Is it growing, declining, or is it stable? In addition to looking at your own company statistics over time, it may be helpful to look at industry-wide averages. The RMA Risk Management Association (formerly named Robert Morris Associates) Annual Statement Studies can be useful here since the studies are organized by NAICS (North American Industry Classification System) industry code and provide benchmark industry ratios for small and medium-sized businesses. Not only are ratios provided for the current year, but for several prior years as well.

\section{Operating Profit Margin}

Operating profit is sales or operating revenue minus operating expenses, such as cost of goods sold, selling expenses, and administrative expenses. Operating profit margin is calculated as operating profit divided by sales (Wild et al., 2007). It indicates what percentage of the sales dollar remains after operating expenses have been deducted or, stated differently, for every sales dollar generated, how much remains to either invest back into the business or to take as profit. Since this ratio examines both the operating revenue and operating expense aspects of the business, the owners can readily spot its significance. Again, further analysis is possible when using this metric as a starting point. Selling expenses as a percentage of sales and general and administrative expenses as a percentage of sales are two readily apparent examples. It is desirable to include recognition of the income tax impact on operating income in this calculation. This would not be applicable if the business is organized as a partnership or a sole proprietorship. To do that, one should perform a calculation in which the total income tax expense is divided by profit before income taxes. The resulting figure, which is a percentage and shows the "income tax bite", can be subtracted from 1.00 and the remaining number, which is the profit after income taxes, should then be multiplied by the operating profit to yield an operating profit after taxes number. It is this figure that can be divided by sales to yield the operating margin ratio. This metric is different than the operating profit margin that was suggested earlier since it takes the impact of income taxes into consideration. As a result, it answers the question, "how did income taxes affect my operating profit?" and it emphasizes that income taxes do have an impact on the company's operating profit.

\section{Net Operating Assets Turnover Ratio}

This measure is the result of dividing the sales revenue by the average net operating assets (Wild et al., 2007). An important consideration here is the inclusion of operating liabilities as a subtraction from operating assets in calculating the denominator in the equation. The operating assets such as accounts receivable, inventories, property, plant and equipment, etc. are included, but from that sum the accounts payable, accrued operating expenses, pensions and other employee benefits, etc. are deducted so as to arrive at a net figure. The net operating asset turnover is a metric that indicates how intensely the company has used its operating assets. For each dollar of net operating assets, the sales volume that has been generated is identified. Ideally, this ratio will improve over time thereby indicating higher productivity.

\section{Free Cash Flow}

This number is gleaned from the cash flow statement and is the cash flow from operations minus capital expenditures (Penman, 2007). As such, the result indicates to the owners the cash that is available for discretionary purposes such as paying off debt or making distribution to the company ownership. Cash is king! 

in Exhibit 1.

If these five metrics are taken together, they indicate how value has been created. This is indicated visually

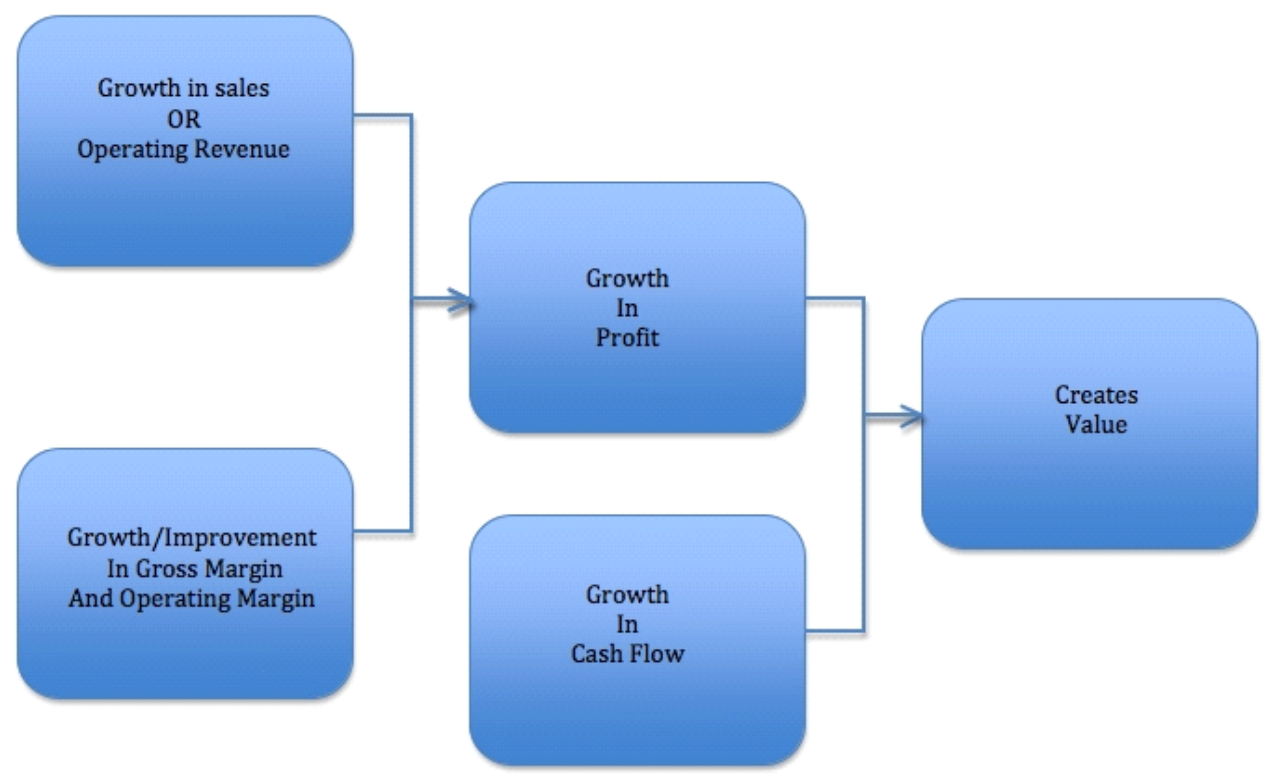

Exhibit 1: Creating Value

\section{CONCLUSION}

Throughout this paper, the authors have been guided by the axiom that has been heard repeatedly - "Make it meaningful, but keep it simple please". There is always the temptation to share more of ones' knowledge and expertise with the people with whom we are dealing. In the case of the small business owner, this has been translated into "please keep it to the fundamentals and I will take it from there". Lest the impression is given that the small business owner is incapable of doing further analysis with these metrics, an additional observation is in order. Small business owners are confronted with a multiplicity of tasks. Literally, they have to be a jack or jenny of all trades. It is a matter of time available and where that time is to be allocated. Hence, this paper has presented a basic serving that is meaningful but not overwhelming. Based on time available, the ownership of the small business can engage in further analysis, seek additional assistance if needed, or engage in other business activities that are deemed to be of a higher priority. At minimum, the metrics presented here provide the foundation for a "good health managerial accounting diet".

\section{AUTHOR INFORMATION}

Ronald J. Patten was dean of the College of Commerce and the Kellstadt Graduate School of Business at DePaul University from 1989 until 1999. Previously he served as dean of the School of Business Administration at the University of Connecticut for 14 years and was head of the Department of Accounting at Virginia Polytechnic Institute and State University for eight years. From 2003 until 2006, he served as Dean of the Graduate School of Management at Ritsumeikan Asia Pacific University in Beppu, Japan. Dr. Patten has worked for the Financial Accounting Standards Board and for Arthur D. Little International. He can be reached at rpatten@depaul.edu.

Charlene Patten is a marketing and beauty industry expert with 20 years of experience leading numerous Procter \& Gamble mega brands, including Pantene, Gillette Venus and Clairol. Since 2011, she has been Vice President and General Manager, Global Brand Franchise Leader of Gillette Venus and Female Shave Care where she leads the global brand strategy, equity, and innovation pipeline for the \#1 female shaving brand in the world with over $\$ 1.6$ billion in retail sales. Previously, Charlene learned the value of brands while working for The Ritz-Carlton Hotel Company. She can be reached at cdpatten3@gmail.com. 


\section{REFERENCES}

- Alexander, David, Britton, Anne, \& Jorisson, Ann. (2005). International Financial Reporting and Analysis ( $2^{\text {nd }}$ ed.). London: Thomson.

- Gibson, Charles H. (2004). Financial Reporting \& Analysis ( $9^{\text {th }}$ ed.). Mason, OH: Thomson.

- Lundholm, Russell, \& Sloan, Richard. (2007). Equity Valuation and Analysis (2 ${ }^{\text {nd }}$ ed.) New York, NY: McGraw-Hill Irwin.

- Penman, Stephen. (2007). Financial Statement Analysis and Security Valuation (3 ${ }^{\text {rd }}$ ed.). New York, NY: McGraw-Hill Irwin.

- Wild, John J., Subramanyam, K. R., \& Halsey, Robert F. (2007). Financial Statement Analysis (9 ${ }^{\text {th }}$ ed.) New York, NY: McGraw-Hill Irwin. 